\title{
Determination of Asphaltene Contents in Residual Oils by Dual Wavelength Spectrophotometry
}

\author{
Yukimasa Fukui ${ }^{\dagger 1) *, ~ S e i g o ~ Y_{\text {AmazoE }}{ }^{\dagger 1)} \text {, Sadao NakaI }}{ }^{\dagger 1)}$, \\ and Hiroshi TsujI ${ }^{\dagger 2}$ \\ 1) Cosmo Research Institute, Analytical Laboratory, \\ 1134-2, Gongendo, Satte, Saitama 340-01 \\ †2) Cosmo Petrotech. Co., Tokyo Laboratory, \\ 3-1-3, Yako, Kawasaki, Kanagawa 210
}

\begin{abstract}
An improved method for the determination of asphaltene contents in residual oils by dual wavelength spectrophotometry has been developed. Contents of $n$-heptane or $n$-pentane asphaltene can be determined from absorbances of suspended sample solutions at 750 and $800 \mathrm{~nm}$. Effects of sample size, particle size of asphaltene and temperature on the absorbance of sample solution were investigated. This method can be applied to a great variety of residual oils such as atmospheric residue, vacuum residue, hydrocracked or thermally cracked residue and bitumens. Time required for the determination of aspaltenes was greatly reduced, using a full automatic asphaltene analyzer (COSMO APD-200A). The relative standard deviation was less than $4 \%$, and the correlation coefficient more than 0.995 proved that the dual wavelength method well correlates with ASTM and IP methods, respectively.
\end{abstract}

\section{Introduction}

Contents of $n$-heptane or $n$-pentane asphaltene in residual oil has been determined, usually, by gravimetric methods. ${ }^{1)} 3$ ) These methods involve complicated operations and require much time. In this situation, a simplified and rapid method for the determination of asphaltene contents has been needed, both for process control and quality control in the petroleum refinery or coal liquefaction plant.

Recently, while some spectrophotometric methods have been reported by Ono,4) Bouquet ${ }^{5)}$ and Kaibara $^{6)}$ for $n$-heptane asphaltene in residual oil, none of these methods could truly be applied universally, because of complex methods and time constraints.

In this study, an improved method for the rapid determination of asphaltene contents ( $n$-heptane or $n$-pentane insoluble matter) by measuring the absorbance of sample solution at 750 and $800 \mathrm{~nm}$ has been developed.

Moreover, a full automatic asphaltene analyzer ${ }^{7}$ (APD-200A) enabled us to determine either $n$ heptane or $n$-pentane asphaltene of 12 samples within 90 minutes. Results obtained by this analyzer are found to well correlate with IP and ASTM methods, respectively.

\section{Experimental}

\subsection{Samples}

Atmospheric residue, vacuum residue, hydrotre- ated coal-derived oil and coal tar pitch were used.

\subsection{Reagents}

$n$-Heptane, $n$-pentane and toluene, of guaranteed reagent grade, were used as solvent.

\subsection{Apparatus}

A Shimadzu UV-210 spectrophotometer was used for the preliminary measurements in the visible range between 550 and $800 \mathrm{~nm}$. Determination of asphaltene contents by dual wavelength absorptometry was carried out with COSMO APD-200 A Full Automatic Asphaltene Analyzer.

Particle size distribution of asphaltene was observed with Nihon Regulator Co., LUZEX-450 Type particle analyzer.

\subsection{Method and Procedure}

The spectrophotometric method was optimized to accommodate from 0.02 to $0.05 \mathrm{wt} \%$ concentration of asphaltene contents.

Suspended solutions of $n$-heptane or $n$-pentane insoluble matters are prepared as follows.

Firstly, 0.5 to $1 \mathrm{~g}$ of a residual oil is dissolved with small amount of toluene for asphaltene determination. Secondly, $100 \mathrm{~m} l$ of hot $n$-heptane $\left(80^{\circ} \mathrm{C}\right)$ or $n$-pentane is added respectively to the above toluene solution. Then it is shaken vigorously to obtain asphaltene suspended solution, finely dispersed, and cooled to room temperature. Thirdly, absorption spectra of homogeneously suspended sample solutions are measured by spectrophotometer at dual wavelengths of 750 and $800 \mathrm{~nm}$, and then asphaltene contents are determined.

* To whom correspondence should be addressed. 


\section{Results and Discussion}

3.1 Measurements of Absorption Spectra and Determination of Asphaltene

Absorption spectrum of an asphaltene suspended sample solution (to be referred as "sample solution"), was measured by spectrophotometer ranging from 650 to $850 \mathrm{~nm}$ with $n$-heptane for reference. A petroleum residual oil was used as a sample.

The spectrum showed monotonous decrease with the increase in wavelength, and there appeared no maximum point, as shown in Fig. 1 .

In order to clarify spectrophotometric contributions of asphaltene ( $n$-heptane insoluble fraction) and maltene ( $n$-heptane soluble fraction), each solution was prepared. Maltene solution was prepared by filtration of sample solution, and asphaltene solution was prepared by addition of asphaltene, isolated previously, into $n$-heptane to obtain same concentration as that of the sample solution.

Absorption spectra of these solutions are con-

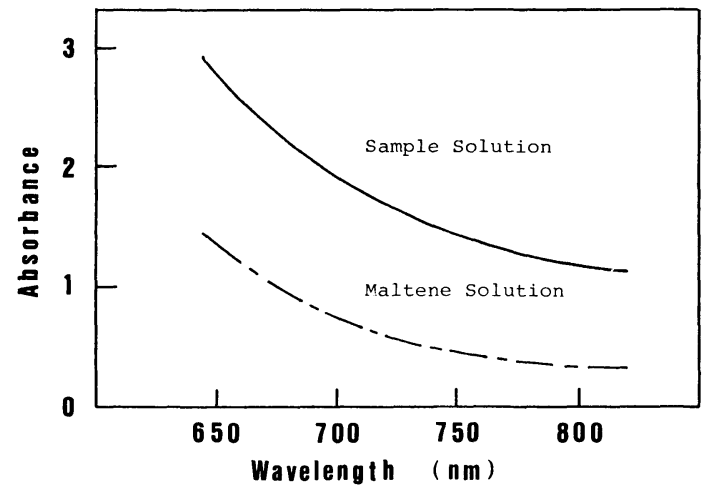

Fig. I Absorption Spectra of Sample Solution and Maltene Solution

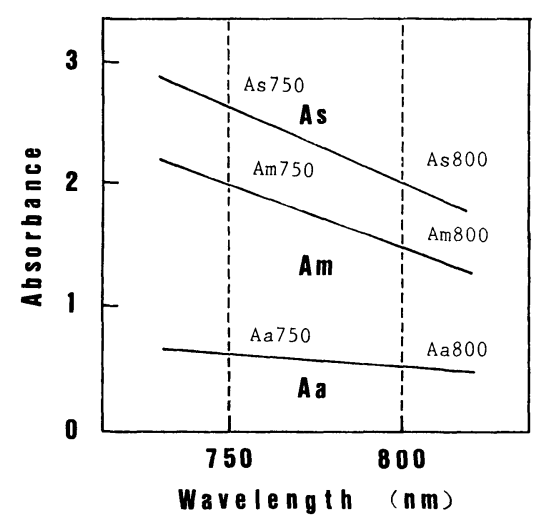

Fig. 2 Conceptual Absorption Spectra of Sample Solution, Maltene Solution and Asphaltene Solution ceptually shown in Fig. 2. It was found that absorbance of a sample solution $(A s)$ is composed of maltene $(A \mathrm{~m})$ and asphaltene $(A a)$, as shown in equation (1).

$$
A s=A m+A a
$$

Equation (1) is expressed to equation (2) at $800 \mathrm{~nm}$.

$$
A s 800=A m 800+A a 800
$$

Since asphaltene particles transmit little light, the absorbance is almost constant in the range of $650-850 \mathrm{~nm}$, and the variance is dependent on the concentration. On the other hand, maltene solutions show different patterns of spectra for various types of oils, and spectrometric gradients between 750 and $800 \mathrm{~nm}$ varied according to the type of oil.

When a sample solution is looked upon as a pseudo solution, it follows Lambert-Beer's law.

$$
A=K \cdot C \cdot t
$$
$A$ : Absorbance,
$C$ : Concentration $(\mathrm{g} / 100 \mathrm{ml})$
$K$ : Absorptivity,
$t$ : Thickness of Cell $(\mathrm{cm})$

Variation of absorptivities $(K)$ of maltene or asphaltene solutions for various kinds of sample oils were each examined. Absorptivity data of maltene and asphaltene solutions on eight samples are shown in Table 1 . Absorptivities of maltenes exhibited different values for all the sample oils, while the ratio of absorptivities at dual wavelengths, 750 and $800 \mathrm{~nm}$, resulted in a constant value, which was also observed in the case of asphaltene. From Table 1, equations (4) and (5) are obtained.

$$
\begin{aligned}
A a 750 & =1.19 A a 800 \\
A m 750 & =1.42 A m 800
\end{aligned}
$$

Substituting equations (4) and (5) to equation (6), equation (7) is obtained.

$$
\begin{gathered}
A s 750 / A s 800=(A s 750+A a 750) /(A m 800+ \\
A a 800) \\
A s 750 / A s 800=0.23(A m 800 / A s 800) \\
+1.19
\end{gathered}
$$

As750: Absorbance of sample oil at $750 \mathrm{~nm}$ As800: Absorbance of sample oil at $800 \mathrm{~nm}$ Am800: Absorbance of maltene fraction at $800 \mathrm{~nm}$

Equation (7) shows the linear relationship 
Table 1 Absorptivities of Maltenes and Asphaltenes for Various Kinds of Residues

$(100 \mathrm{ml} / \mathrm{gr} \cdot \mathrm{cm})$

\begin{tabular}{|c|c|c|c|c|c|c|}
\hline \multirow{2}{*}{ Sample } & \multicolumn{3}{|c|}{ Maltene } & \multicolumn{3}{|c|}{ Asphaltene } \\
\hline & K 750 & K 800 & K $750 /$ K 800 & K 750 & K 800 & K $750 /$ K 800 \\
\hline $\begin{array}{l}\text { AL/AR } \\
\text { AH/AR } \\
\text { BS/AR } \\
\text { IH/AR/HCR } \\
\text { MB/AR/HCR } \\
\text { AL/AR/HCR } \\
\text { KF/AR/HCR } \\
\text { AH/VR/TCR }\end{array}$ & $\begin{array}{l}0.133 \\
0.325 \\
0.753 \\
0.273 \\
0.040 \\
0.227 \\
0.381 \\
0.415 \\
\end{array}$ & $\begin{array}{l}0.094 \\
0.229 \\
0.530 \\
0.191 \\
0.028 \\
0.160 \\
0.270 \\
0.290 \\
\end{array}$ & $\begin{array}{l}1.41 \\
1.42 \\
1.42 \\
1.43 \\
1.42 \\
1.42 \\
1.41 \\
1.43 \\
\end{array}$ & $\begin{array}{l}53.7 \\
52.7 \\
51.2 \\
53.9 \\
52.8 \\
54.3 \\
53.1 \\
52.9 \\
\end{array}$ & $\begin{array}{l}45.5 \\
44.3 \\
43.0 \\
45.3 \\
44.0 \\
46.0 \\
44.6 \\
44.5 \\
\end{array}$ & $\begin{array}{l}1.18 \\
1.19 \\
1.19 \\
1.19 \\
1.20 \\
1.18 \\
1.19 \\
1.19\end{array}$ \\
\hline$\overline{\mathrm{X}}$ & & & 1.42 & & & 1.19 \\
\hline
\end{tabular}

AL:Arabian Light AH:Arabian Heavy BS:Boscan MB:Murban IH:Iranian Heavy

KF:Khafji AR:Atmospheric Residue VR:Vacuum Residue HCR:Hydrocracked Residue TCR: Thermally Cracked Residue

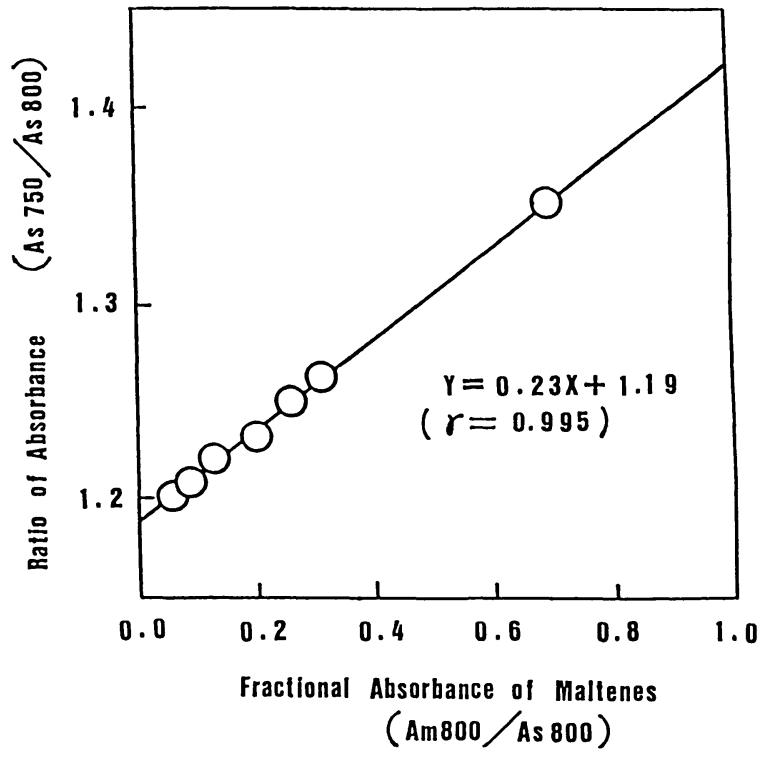

Fig. 3 Linear Relationship between Fractional Absorbance of Maltene and Ratio of Absorbances at Dual Wavelength

between fractional absorbances of maltenes and ratio of absorbances at two wavelengths of 750 and $800 \mathrm{~nm}$, respectively. It is realized that absorbance ratio of sample solution at two wavelengths results in value between 1.19 and 1.42 . When the fraction of asphaltene absorbance in a sample solution increases, the ratio of absorbance $(A s 750 / A s 800)$ approaches 1.19. By the increase of maltene fraction, the ratio will approach 1.42. It was found that sample oil solutions exhibited absorbance ratio within a range of 1.19 and 1.42 , as shown in Fig. 3, which is plotted with data in Table 2.

Working curve of asphaltene concentration versus absorbance is expressed as equation (8).

$$
C a=0.025 \cdot A a 800
$$

Table 2 Absorbances of Various Kinds of Sample Oil Solution

\begin{tabular}{c|c|c|c|c}
\hline \multirow{2}{*}{ Sample } & \multicolumn{2}{|c|}{ Absorbance } & \multirow{2}{*}{$\begin{array}{c}\text { Ratio } \\
\text { As 750/ } \\
\text { As 800 }\end{array}$} & $\begin{array}{c}\text { Ratio } \\
\text { Am 800/ } \\
\text { As 800 }\end{array}$ \\
\cline { 2 - 3 } & @ 750 nm & @ 800 nm & 1.20 & 0.058 \\
1 & 1.91 & 1.51 & 1.21 & 0.083 \\
2 & 1.95 & 1.61 & 1.22 & 0.125 \\
3 & 1.61 & 1.32 & 1.23 & 0.199 \\
4 & 1.89 & 1.54 & 1.25 & 0.258 \\
5 & 2.09 & 1.67 & 1.26 & 0.307 \\
6 & 1.16 & 0.92 & 1.35 & 0.691 \\
7 & 0.49 & 0.36 & \multicolumn{3}{|c}{} \\
\hline
\end{tabular}

Aa800: Absorbance of asphaltene fraction at $800 \mathrm{~nm}$

Ca : Asphaltene concentration in sample solution $(\mathrm{g} / 100 \mathrm{ml})$

Asphaltene concentration in the residual oil can be calculated from equations (2), (7) and (8) by eliminating parameters of $A a 800$ and $A m 800$

\subsection{Effect of Particle Size}

It was found that a narrow range of particle size distribution for ample solution is necessary to obtain accurate data of asphaltene contents. When sample solutions of asphaltene suspension are prepared only with $n$-heptane, wide range (1-100 $\mu \mathrm{m})$ and different patterns of particle size distribution are obtained for various kinds of residual oils, and remarkable fluctuation for asphaltene contents were observed. However, with the pretreatment of $1 \mathrm{~m} l$ toluene before addition of $100 \mathrm{~m} l n$-heptane, narrow particle size distribution within the range of $5 \mu \mathrm{m}$ max. can be obtained, regardless of the residual oil source, as shown in Fig. 4.

Effect of toluene on the absorbance of sample solution was further investigated. Results are shown in Fig. 5. Absorbances at $800 \mathrm{~nm}$ were constant with the addition of not more than $1 \mathrm{ml}$ of toluene, while, excess volume of toluene of more than $1 \mathrm{ml}$ decreased the absorbance of 


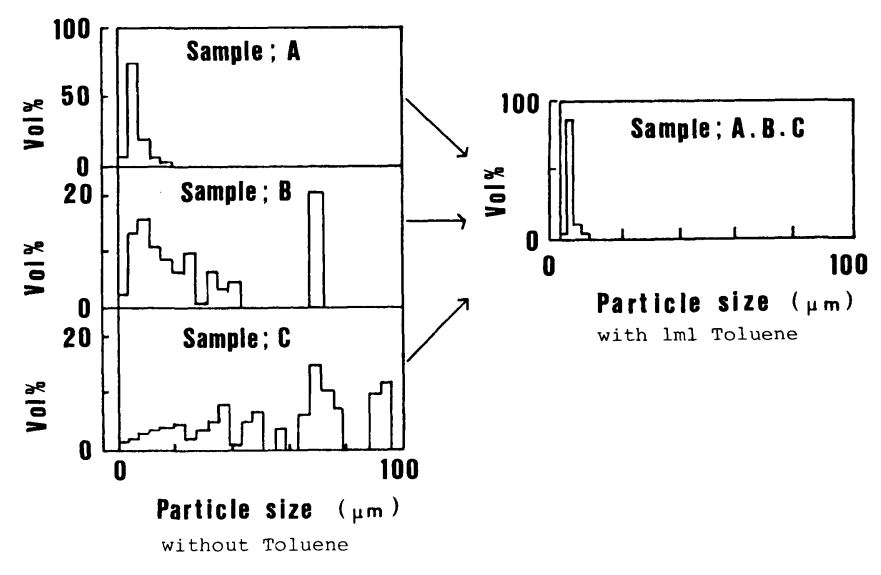

* Sample solution was prepared with $1 \mathrm{ml}$ of Toluene. Sample A : Arabian Light Atm. Residue (Asphaltene 2.4\%) Sample B : Arabian Heavy Atm. Residue (Asphaltene 4.7\%) Sample C : Boscan Atm. Residue (Asphaltene 12.4\%)

Fig. 4 Effect of Toluene on Particle Size Distribution of Asphaltene in Sample Solution

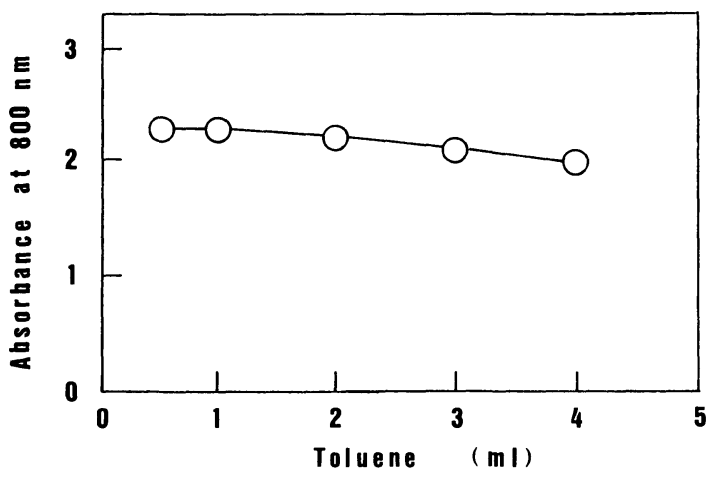

Sample B, Sampl Size $1 \mathrm{~g}$

Fig. 5 Effect of Toluene on Absorbance of Sample Solution

sample solution. It was found that $1 \mathrm{ml}$ of toluene is suitable for the determination of asphaltene contents when using 0.1-1 $\mathrm{g}$ of sample oil.

\subsection{Effect of Sample Size}

Absorbance of suspended solution depends on the sample size, namely, amount of asphaltene, as shown in Fig. 6. Linear relationships between sample size and absorbances at $800 \mathrm{~nm}$ were observed in the absorbance unit range of $0.5-3.0$, for three kinds of residual oils. When absorbance is over 3.0, sample size should be decreased so as to bring it in the range from 0.5 to 3.0. When absorbance is under 0.5 , amount of sample may be increased to $3.0 \mathrm{~g}$, which is the upper limit of neglecting solubilization of asphaltene with maltene.

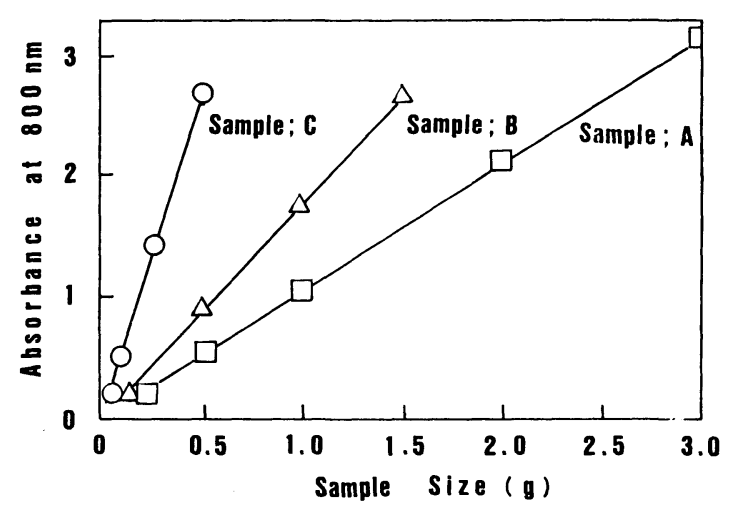

Fig. 6 Effect of Sample Size on Absorbance at $800 \mathrm{~nm}$

\subsection{Effect of Temperature of Sample Solution}

Effect of temperature of $n$-heptane on the absorbance of sample solution was investigated. Absorbance of sample solution increased with raise in the temperature of $n$-heptane, which was added to the preheated residual oil with toluene, as shown in Fig. 7. It is supposed that asphaltene particle was previously solubilized with toluene molecules to form unit miscelle. Further, by addition of hot $n$-heptane to the miscellaneous solution, miscelle was broken gradually and coagulated to regulated size of particles.

Degree of coagulation is supposed to proceed with hot $n$-heptane. Asphaltene particles once solubilized with toluene molecules would be peeled off by hot $n$-heptane and flocculate each other. 


\subsection{Application to Determination of $\boldsymbol{n}$-Pentane Insolubles}

Technics of determination of $n$-heptane insolubles were also applied to $n$-pentane insolubles. Suspended solution of $n$-pentane insolubles be-

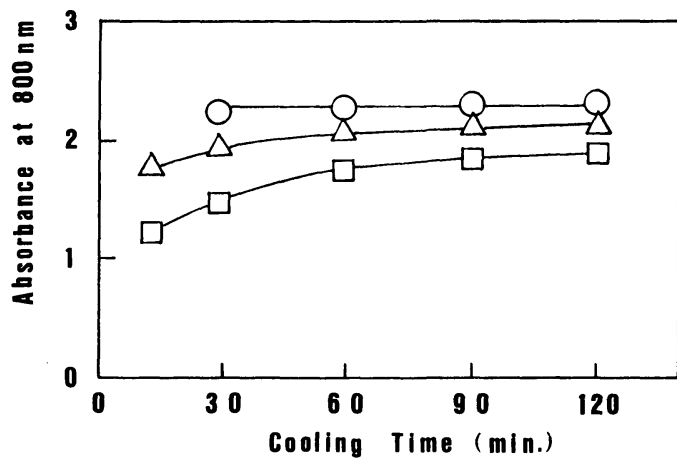

$\square: 25^{\circ} \mathrm{C} \quad \triangle: 50^{\circ} \mathrm{C} \quad \mathrm{O}: 80^{\circ} \mathrm{C}$

Fig. 7 Effect of Temperature of Sample Solution and Cooling Time on Absorbance at $800 \mathrm{~nm}$

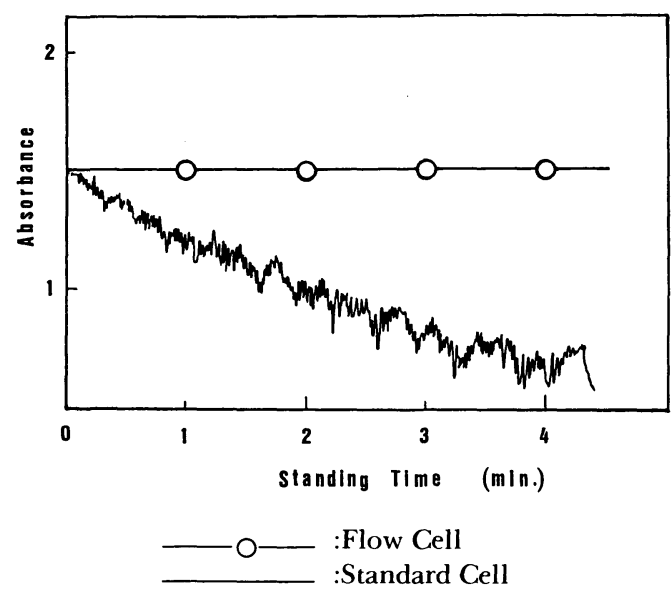

Fig. 8 Effect of Standing Time on the Absorbance of $n$-Pentane Insoluble haved the same as in the case of $n$-heptane asphaltene, although the particles of $n$-pentane insoluble are unstable in the solution and apt to settle, as shown in Fig. 8. In order to solve this problem it is inevitable that absorbance be measured under flowing state using the flow cell.

\subsection{Analytical Accuracy}

A full automatic analyzer has been developed for rapid determination of asphaltene by measuring the absorbances at dual wavelengths. Schematic diagram of the analyzer is shown in Fig. 9. Five kinds of residual oils including different concentration of asphaltene were analyzed six times, repeatedly, by using this instrument. Coefficients of variation are under $4 \%$, as shown in Table 3 . It was found that dual wavelength spectrophotometry is an excellent method with good repeatability for determination of asphaltene, more than any other methods such as conventional gravimetry or spectrophotometry.

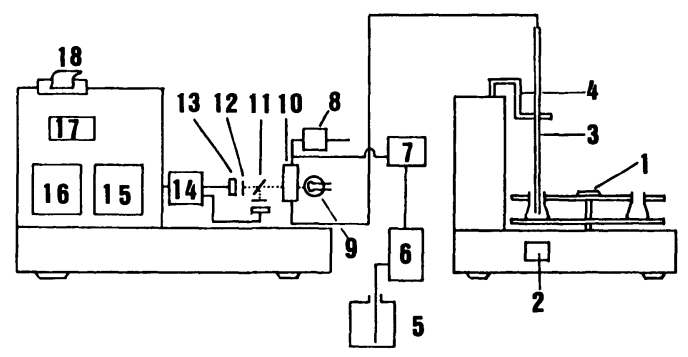

1. Turn Table, 2. Stirrer, 3. Suction Nozzle 4. Elevator 5. Washing Solvent Reservoir 6. Pump 7. Valve 8. Pump 9. Light Source 10. Flow Cell 11. Sector Mirror 12. Interference Filter 13. Photo Cell 14. Amplifier 15. AD Converter 16. Micro Processor 17. Display 18. Printer

Fig. 9 Schematic Diagram of Asphaltene Analyzer

Table 3 Repeatability of Determination of Asphaltene by Dual Wavelength Method

\begin{tabular}{|c|c|c|c|c|c|}
\hline No. & $\begin{array}{l}\text { Hydrocracked } \\
\text { Residue }\end{array}$ & $\begin{array}{c}\text { Atmospheric } \\
\text { Residue } \\
\text { (Khafji) }\end{array}$ & $\begin{array}{l}\text { Vacuum } \\
\text { Residue } \\
\text { (Khafji) }\end{array}$ & $\begin{array}{c}\text { Thermally } \\
\text { Cracked } \\
\text { Residue }\end{array}$ & $\begin{array}{c}\text { Oil Sand } \\
\text { Bitumen } \\
\text { (Asabasca) }\end{array}$ \\
\hline $\begin{array}{l}1 \\
2 \\
3 \\
4 \\
5 \\
6\end{array}$ & $\begin{array}{l}1.30 \\
1.26 \\
1.27 \\
1.30 \\
1.30 \\
1.27\end{array}$ & $\begin{array}{l}5.19 \\
5.70 \\
5.37 \\
5.28 \\
5.26 \\
5.50\end{array}$ & $\begin{array}{l}12.1 \\
12.5 \\
12.2 \\
12.1 \\
12.0 \\
12.2 \\
\end{array}$ & $\begin{array}{l}22.3 \\
22.5 \\
22.7 \\
22.3 \\
22.5 \\
22.3 \\
\end{array}$ & $\begin{array}{l}18.1 \\
17.8 \\
18.4 \\
18.1 \\
17.9 \\
18.4 \\
\end{array}$ \\
\hline $\begin{array}{l}\bar{X} \\
\text { SD } \\
\mathrm{CV}(\%)\end{array}$ & $\begin{array}{l}1.28 \\
0.02 \\
1.45\end{array}$ & $\begin{array}{l}5.38 \\
0.18 \\
3.49\end{array}$ & $\begin{array}{c}12.2 \\
0.17 \\
1.41\end{array}$ & $\begin{array}{c}22.4 \\
0.16 \\
0.73\end{array}$ & $\begin{array}{c}18.1 \\
0.15 \\
1.37\end{array}$ \\
\hline
\end{tabular}




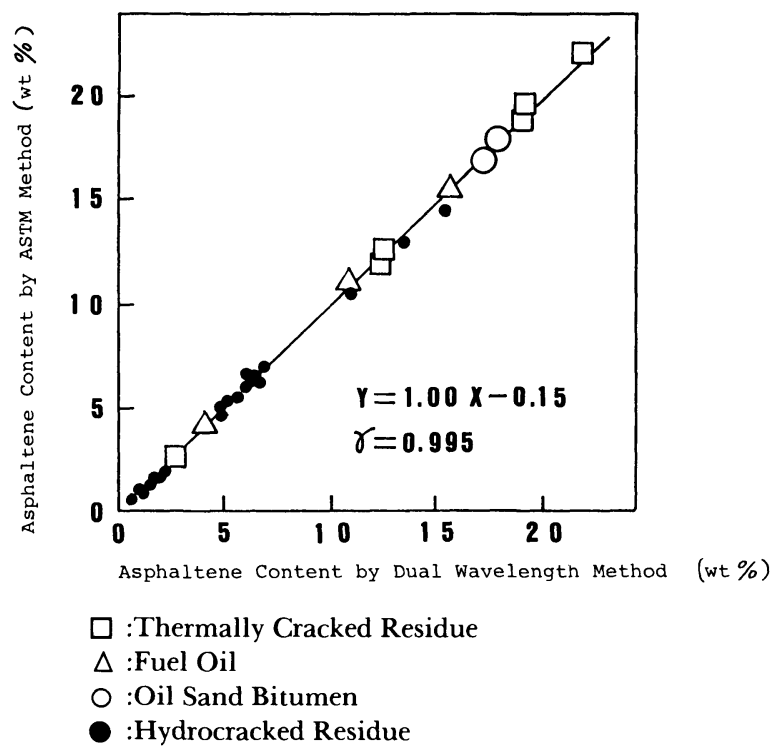

Fig. 10 Correlation between ASTM Method and Dual Wavelength Method

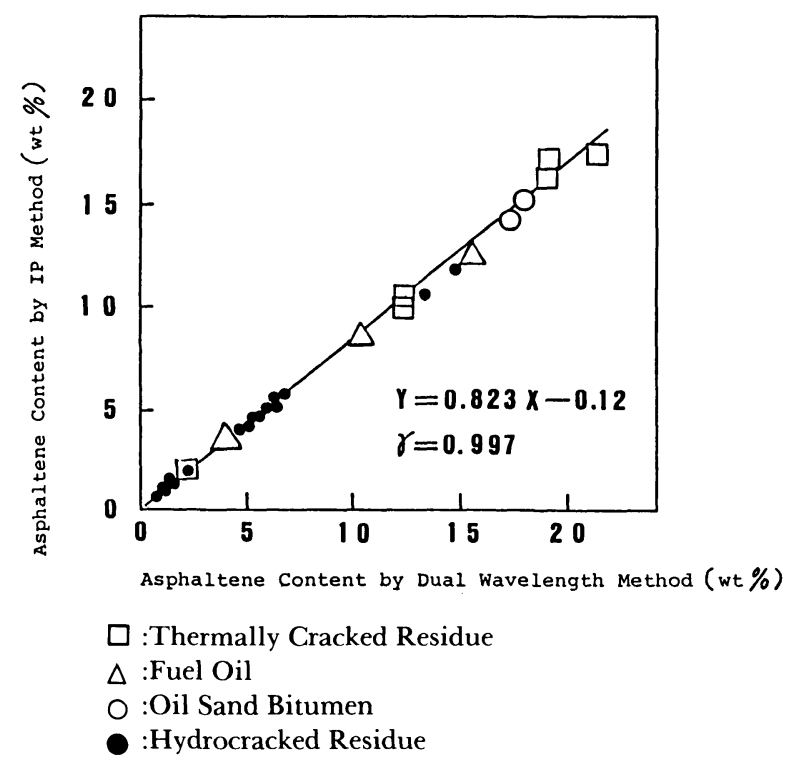

Fig. 11 Correlation between IP Method and Dual Wavelength Method

\subsection{Correlation between Improved Method and Standard Method}

Correlation between improved method and ASTM and/or IP method were obtained by using samples of oils from various sources. Results are shown in Figs. 10 and 11, respectively. Correlation coefficients of more than 0.995 proves that dual wavelength method is correlative with standard methods.

\section{Conclusion}

1) An improved method has been developed for the determination of $n$-heptane or $n$-pentane asphaltenes to realize rapid determination with good repeatability. Good repeatability was obtained by forming size controlled particle through adding small amount of toluene to the sample.

2) Measurements obtained with a full-automatic asphatlene analyzer (APD-200A) have shown good correlation with those of standard methods: ASTM D 3279-83, IP-143/82.

3) Application of the flow cell is also effective in the determination of precipitable $n$-pentane insoluble matter.

\section{References}

1) ASTM D 3279-83 "Standard Test Method for $n$ HEPTANE INSOLUBLES".

2) IP-143/82 "ASPHALTENES PRECIPITATION WITH NORMAL HEPTANE".

3) UOP-614/84 "HEPTANE-INSOLUBLE MATTER IN PETROLEUM OILS USING A MEMBLANE FILTER".

4) Ono, T., J. Japan Petrol. Inst., 14, (7), 504 (1971).

5) Bouquet, M., et al., Fuel, 641625 (1985).

6) Kaibara, T., et al., J. Japan Petrol. Inst., 23, (3), 178 (1980).

7) Fukui, Y., International Laboratory, Jan/Feb. edition, $30,(1988)$.

8) Tsuji, H., Yamazoe, S., Nakai, S., Fukui, Y., "Symposium on Petroleum Product", JPI preprint, P. 84-88, Oct. 22 (1987). 


\author{
福井 行正 ${ }^{\dagger 1)}$, 山添 誠吾 ${ }^{\dagger 1)}$, 中井 貞夫 ${ }^{\dagger 1)}$, 辻 浩 ${ }^{\dagger 2}$ \\ †1)(株)コスモ総合研究所, 340-01埼玉県幸手市権現堂 1134-2 \\ †2)コスモペトロテック(株)東京試験室, 210 神奈川県川崎市川崎区夜光 3-1-3
}

2 波長吸光光度法による残油のアスファルテン迅速定量法を 開発した。常圧残油, 隇圧残油, 水素化分解残油, 熱分解残 油, 接触分解残油およびビチューメン等の試料に $n$-ペンタン または $n$-ヘプタンを一定量加えてアスファルテン懸濁液を作 り，750および $800 \mathrm{~nm}$ における吸光度を測定した。試料懸濁 液の吸光度はマルテンおよびアスファルテン吸光度からなり (Fig. 2), 各成分を分離してそれぞれの吸光度を求めた結果, 油種によって吸光度は異なるものの, 各波長に扔ける吸光係数 の比（K 750/K 800）は油種に関係なく一定值（Table 1)を とることが分かった。また試料懸濁液の吸光度に占めるマルテ
ンの吸光度分率は, 各波長における試料懸濁液の吸光度比 (As 750/As 800）との間に直線関係にあることが分かり（Fig. 3), 検量線をはじめとする関係式 (Eq. 2, 4,5) からアスファルテ ンを定量することができた。予め試料にトルエンを加えて溶解 させた後, 懸濁液を調製したとき,アスファルテン粒子径を $5 \mu \mathrm{m}$ 以内に揃えることができ（Fig. 4)，すぐれたくり返し精 度が得られた（Table 3)。試料採取量の影響（Fig. 6) および 試料懸濁液調製時における温度と放冷時間の影響（Fig. 7）に ついてもしらべた。本法による定量值は現行の ASTM 法およ び IP 法とよい相関関係を示した（Fig. 10, 11）。

\title{
Keywords
}

Residual oil, Asphaltene, Spectrophotometry 